\title{
Study on the Content System Construction of Humanistic Care in Ideological and Political Education
}

\author{
Bin Yang \\ Yunnan College of Business Management, Kunming, Yunnan, 650106
}

Keywords: Humanistic Care, Ideological and Political Education, System Construction

\begin{abstract}
The ideological and political education in China has a wide range of goals. Students, college employees, and other social personnel in major universities are exposed to ideological and political education. The level of development of ideological and political education is directly related to the cultivation of the mental outlook of students, employees and other social masses, as well as the improvement of humanistic qualities, helping people to improve their adaptability and adapting to the learning environment of schools and society more quickly. It can improve people's moral values, standardize people's social behaviors, and contribute to building a socialist harmonious society.
\end{abstract}

\section{Introduction}

Ideological and political education is mainly a social-based educational activity centered on people, with strong humanistic care connotation, including cultivating people, shaping people, and developing people. From a philosophical point of view, ideological and political education is actually a process of building people and exploring the meaning of human existence. Ideological and political education plays an important role in creating a spiritual home and promoting the all-round development of human beings. This is also the expression of humanistic care. In addition, from the main body of ideological and political education, both educated and educated people are people. In other words, ideological and political education is the process of educating and cultivating people. People communicate and influence each other. Ideological education is also a kind of humanistic care.

\section{Profound connotation of humanistic care}

The connotation basis of humanistic care is very rich. Humanistic care is the tangible solution and mastery of people's needs and development direction and goals. With the development of modern society, people as the smallest unit of society, its stable demand and development will affect the vital factors of social process, so humane care has become a very important part of the social process. What humanistic care advocates is the all-round development of the individual. This is in line with the trend and principle of social development and progress, and it is in line with the spirit of the times that keeps pace with the times.

The construction of social economy is inseparable from human support, and the expression of personal will is not only a manifestation of individual needs, but also one of the driving forces for the development of various undertakings. Humanistic care takes people's needs and development as the starting point. Whether it is from a personal point of view or from the perspective of social development, respecting the expression of individual wishes and giving individuals the opportunity to express their wishes is an indispensable part of humanistic care. At the same time, giving individuals the opportunity and space to express their wishes can make ideological and political education more flexible. While deepening understanding of individual needs and development foundation, it can also promote the in-depth development of ideological and political education and promote humanistic care. The construction of the system makes the work of ideological and political education more humane. It is easier for educators and people who receive ideological and political education to understand and communicate, and the views and contents of ideological and 
political education are more acceptable.

As the smallest unit of human society, the individual's development potential is unlimited, and it has unlimited creative space. And to promote faster and better development of society, it is inseparable from the excellent creativity of individuals. If one wants to develop people's excellent creativity, it needs many factors to promote the unlimited development of its creativity. In this promotion process, individual creativity needs individual guidance and external factors to stimulate and stimulate. It is precisely this role that guides and inspires. Its nature is to actively mobilize individual thinking and imagination, guide individuals to think independently, apply their ideas and ideas to the development of specific things, and create new ideas. Or things, this is the specific application and embodiment of personal creativity. This creative concept and guiding method can bring people's creativity into social change and development and become a driving force for social change and development.

\section{Main contents of humanistic care in ideological and political education}

Maslow divides people's needs into five levels, including five levels of physiology, safety, belonging, respect and self-realization. In addition, Maslow believes that only low-level needs are met before they want to meet advanced needs. Therefore, the humanistic care of ideological and political education needs to care for and meet people's needs. Human needs include both material and spiritual aspects, and human care concerns more about spiritual needs.

The rapid development of society makes people's needs change from low to high levels. After meeting basic material needs, spiritual needs will increase. Because of the different environments, people have a variety of spiritual needs, as well as spiritual needs, some people will pursue moral sentiment, and some will pursue low taste. Ideological and political education Humanistic care not only stays in the material needs, but also focuses on improving people's spiritual civilization and helping people to rise from material interests to shaping the ideal personality and other spiritual aspects. As the society is in a special period of transformation, some people can not adapt to the transformation of society, which leads to confusion. The ultimate goal of ideological and political education humanistic care is to help people create spiritual homes. Creating a spiritual home is the ultimate concern of humanistic care. The most fundamental thing is to let people realize the meaning of life and reach the realm of spiritual freedom and spiritual freedom. It is also the ultimate goal of modern education.

\section{Problems in current ideological and political education}

China's current ideological and political education model also continues the past practice, with teachers as the main role in the entire educational process, while students passively accept, learn and master relevant knowledge concepts, and recognize the importance and significance of ideological and political education. Flowing on the surface, there is a serious deficiency in its deep understanding. This is due to the incomplete understanding of the concepts and methods of education in modern education. Modern education should be based on students. Students must not only master basic concepts and knowledge, but also understand the meaning and connotation of ideological and political education. To shape students' perfect personality and correct values, and to promote the overall development of students' comprehensive quality. The current ideological and political education model confuses the teacher and the student's primary and secondary, making the ideological and political education work unable to achieve its proper teaching effect, but instead becomes a face-to-face work that perfunctory and perfunctory.

As a basic and comprehensive education, ideological and political education plays an important role in promoting the all-round development of human beings. However, in the traditional ideological and political education mode, the understanding of the meaning, purpose and concept of ideological and political education exists. Limitations. With the development of the times, this limitation should be gradually broadened and broken with the progress and development of society. However, due to the lag of China's spiritual civilization construction work, the current 
understanding of ideological and political education still remains in the old era. The education method is also completely mechanical infusion, the modern teaching methods are not introduced, and the new ideas emerging in the new era are rejected, leading to boring and boring ideological and political education courses, giving people a sense of cliché and making students I am disgusted with the ideological and political education curriculum, which has led to the failure of the ideological and political education work to perfect the cultivation of people's character, quality and concept. Eventually, the ideological and political education work has become a complete formalization process. The ribbed work did not exert its true influence.

\section{Strategies for constructing the content system of humanistic care in ideological and political education}

The ideological and political curriculum has strong pertinence in both content and form. When different arguments appear, the main points of learning will become more abundant. Therefore, in the process of teaching, we must strengthen diversified ideological and political teaching. Ways and methods to form a diverse form of teaching. For example, when teachers explain the three representative ideas, teachers can use group discussion to conduct group discussion and analysis on the core content, so that students have a deeper understanding of the three representative ideas. After analysis and discussion, students are encouraged to express their views on the three representative ideas, so that students can develop a habit of paying attention to socialist construction and have a better understanding of China's national conditions.

The combination of the theory and practice of ideological and political education can enable students to have a certain understanding of society earlier. While carrying out ideological and political practice activities, the content of people's cultural care has penetrated into the activities and actively carried out relevant volunteer activities. For example, the activities of teaching in the countryside will enable students to personally feel the teaching environment in poor mountain areas and the desire of children in mountainous areas to learn, thus stimulating students' learning motivation.

Teachers play an extremely important role in the entire teaching activities. Teachers of ideological and political courses have higher requirements and need higher professional quality. Students' learning is most in need of interest. Teachers should fully mobilize students' interest in learning and strengthen the guidance of humanistic care content. In the daily teaching process, when there is a certain error in the student's speech or judgment, the teacher tries to avoid positive criticism. The biggest characteristic of college students is that they have strong self-esteem. Teachers fully respect the self-esteem of students, and students will accept the suggestions and criticisms put forward by teachers and take the initiative to correct them. In addition, teachers should appropriately encourage and affirm students with poor performance to help students establish self-confidence in learning. In response to the content of the ideological and political education curriculum, teachers can help students to summarize and summarize, and create a relaxed learning environment.

With the advancement of China's market economy construction, people's material life is becoming more and more abundant, but the spiritual world has become more and more empty, and even a few people's social moral concepts are worrying. Therefore, it is necessary to constantly improve and strengthen the spirit. The building of civilization, thereby improving moral standards. The construction of spiritual civilization is an important part of humanistic care. In terms of improving spiritual civilization construction, we can start from the following two aspects: First, adhere to Marxism as the guiding ideology and establish a correct concept of honor and disgrace. Second, with socialism with Chinese characteristics as the core, strengthen patriotic education and promote the improvement of students' spiritual civilization.

\section{Conclusion}

With the continuous improvement of China's educational level, the concept of people-oriented 
has also been developed and continued. Ideological and moral education has become extremely important in the education work, the most important of which is humanistic care. At present, China's ideological and political education still has some defects in the construction of humanistic care content system, which needs constant improvement. This is a long process and requires the joint efforts of educators. In addition, as a staff member of ideological and political education, we must be aware of the importance of humanistic care. In daily education activities, we need to continuously strengthen our personality strength and promote the development of ideological and political education in our country.

\section{References}

[1] Zhang Yumin, Sun Yu. Discussion on the Construction of Content System of Humanistic Care in Ideological and Political Education[J].Journal of Yunnan Administration College,2013,(2):76-77.

[2] Cheng Jingxiu, Tan Yueyu. The Content System Construction of Humanistic Care in Ideological and Political Education [J]. Youth and Society, 2013(24): 220-220.

[3] Xing Menghua, Li Jun. The content system construction of humanistic care in ideological and political education [J]. Urban Tutor (first half of the month), 2016 (3): 153-153.

[4] Meng Yu. The Content System Construction of Humanistic Care in Ideological and Political Education[J]. Science and Fortune, 2016(4): 291-291.

[5] Song Jinsong, Wang Bin. A Summary of the Research on Humanistic Care Theory in Ideological and Political Education [J]. Research on Ideological and Political Education, 2008, 05: 21-25. 